\title{
Red Stripe/ Top Rot Disease of Sugarcane: A Review
}

\author{
Rakesh Yonzone $^{1}$ and Maimom Soniya Devi ${ }^{2 *}$ \\ ${ }^{1}$ College of Agriculture (Extended Campus), Ubkv, Majhian, Dakshin Dinajpur, \\ West Bengal-733133, India \\ ${ }^{2}$ Department of Entomology, Bidhan Chandra Krishi Viswavidyalaya, Mohanpur, \\ West Bengal-741252, India \\ *Corresponding author
}

\section{A B S T R A C T}

\section{Keywords}

Sugarcane, Cash crop, Red stripe/top rot, Acidovorax avenae subsp. Avenae, Disease

Article Info

Accepted:

12 December 2017

Available Online:

10 January 2018
Sugarcane (Saccharum officinarum L.) is one of the world's most important cash crop cultivated in more than 80 countries around the globe. There are several impediments which contribute to low cane yield and one of the factors is plant diseases. The crop is mostly constrained by diseases of fungal, bacterial and viral origin. Bacterial Red stripe/top rot incited by Acidovorax avenae subsp. Avenae once considered to be the minor disease is gaining importance these days. The disease mostly occurs in two forms i.e., leaf stripes and top rot, which may occur singly or together under field condition during relatively high atmospheric humidity. The bacterial nature of the disease was first established by Lee and Jennings in 1924. The pathogen has wide host range and is spread by wind and rain in warm humid weather causing a true vascular disease in sugarcane.

\section{Introduction}

Sugarcane (Saccharum officinarum L.) is one of the world's most important crop plants and is cultivated in tropical and subtropical areas in more than 80 countries around the globe. The important sugarcane producing countries in the world are India, Cuba, Brazil, Mexico, Pakistan, China, Philippines, Columbia, Argentina, Australia, USA, Thailand, and South Africa. In India it is grown on 5.0 million hectare with total production of 338.963 million tonnes that contributes nearly 75 per cent to the total sugar (Anonymous
2015). It is one of the most important cash crops, contributing about 7.5 per cent of the gross value of agricultural production in the country. Cultivated sugarcane might have originated in Oceania, most probably in NewGuinea, where some closely related forms of thick, tall canes and wild species of Saccharum spontaneum are still found. The sugarcane is an important source of sugar and related products. Sugarcane in India is being cultivated throughout the country except in certain hilly tracts in Kashmir and Himachal Pradesh. The main cane growing states are Uttar Pradesh, Uttaranchal, Bihar, Punjab and 
Haryana. Uttar Pradesh is the leading state in growing sugarcane in India but average yield per hectare is highest in Tamil Nadu, Maharashtra and Karnataka. In Punjab it is cultivated in about 94 thousand hectare of land with an average cane production of 7.05 million tones (Anonymous, 2015).There are several impediments which contribute to low cane yield in India and one of the factors is plant diseases. Sugar production is constrained by diseases of fungal, bacterial and viral origin. The bacterial disease namely leaf scald, ratoon stunting, gummosis and red stripe are found sporadically in many sugarcane tracts of the country. Often, these diseases become epidemic to cause considerable loss to the crop. Thus, this commercial crop which supports our agrobased industry suffers loss and with further intensification of cultivation of the crop, might lead to more loss to the nation, unless adequate steps are taken to control the diseases (Rangaswami, 1975). Red rot (Colletotricum falcatum), smut (Ustilagosci taminea), wilt (Cephalosporium sacchari), grassy-shoot disease (mycoplasma like bodies) and ratoon-stunting disease (Clavibacter xyli sub sp. xyli) are important under Punjab conditions.

\section{Red stripe/top rot disease}

Red stripe/top rot disease once considered as a minor disease of sugarcane is gaining importance as a major disease due to considerable changes in the climatic factors. This disease mostly occurs in two forms i.e., leaf stripes and top rot, which may occur singly or together under field condition having relatively high atmospheric humidity. Red stripe first appears on basal part of the young leaves of the spindle/crown as watersoaked, long narrow chlorotic streaks usually midway in the leaf and near the midrib but in some instances the stripes are concentrated towards the leaf base and mostly the lower half of the leaf is generally more affected than the upper half. These stripes may be 0.5 to 1 $\mathrm{mm}$ in width and 5 to $100 \mathrm{~mm}$ in length (Rangaswami and Rajagopalan, 1973). In Hawaii (Martin, 1938), Java (Bolle, 1929), Taiwan (Okabe, 1933) and Louisiana (Rands and Dopp, 1932) young ratoon were found to be more subjected to infection than plant canes of the same age but in Australia, Cottrell-Dormer (1932) reported the opposite case. Fors (1978) observed red coloured blotches on stalks in the region of root primordia extending towards the internodes in the form of thick red lines in B 4362. Red stripe occurs mostly on the young and middleaged leaves, rather than on the older leaves of the plant. The disease may attack the youngest leaves which are partially unrolled and, if incidence is severe, causes a top rot. Top rot on the other hand may result from stem or bud infection without exhibiting leaf symptoms, as well as from leaf infection. As the name indicates, this stage of the disease refers to the rotting of the terminal portion of the stalk. Leaf sheaths attached to affected internodes often manifest reddish discolouration on the outside and reddish splashes on the inner surface which reach almost to the leaf joint (Cottrell-Dormer 1932). Affected internodes frequently exhibit sunken areas which are first water-soaked in appearance and which later turn brown-to-red in colour. Stalks with top rot are retarded in growth and usually die, the tops frequently break off and fall to the ground. Canes infected with top rot emit a characteristic unpleasant odour (Martin and Wismer, 1961). In North India symptom were reported to appear from July to August and the infection may result from stem, bud and / or leaf (Rana and Shukla, 1968).

\section{Occurrence, distribution and losses}

Red stripe disease was first observed in Hawaii by Lyon (1922) and there after it was 
reported from most of the cane growing area (Ricaud et al., 1989; Martin and Wismer 1961). It was subsequently named red stripe or bacterial red stripe (Lee and Jennings, 1924). Tryon (1923) reported top rot condition of sugarcane in Queensland and later reported from 50 sugarcane growing countries in the world. The red stripe disease is generally considered as minor importance (Edgerton, 1959; Martin and Wismer, 1961) but the pathogenic potentiality of pathogen to cause epidemics has also been reported (Chona and Rao, 1963; Fors, 1978). In 2006 Patro and his co-worker considered it as one of the most important and economically a dreadful disease of sugarcane. The disease has also been reported from Louisiana (Christopher and Edgerton, 1930), Florida (Rands and Dopp, 1932), Cuba (Faris, 1927), Philippines (Lee and Pierce, 1928), Puerto Rico (Cook, 1929) Brazil (Grillo, 1938), India (Subramaniam, 1936), and Taiwan (Matsumoto, 1952). In India its first appearance was reported by Desai in 1933 and was subsequently reported from several other states on many sugarcane varieties (Dange and Payak, 1973; Agnihotri, 1990). Chona and Rao (1963) reported the occurrence of Red stripe disease in an epidemic form around Delhi and in the eastern districts of Punjab.

They further reported that cane variety $\mathrm{Co}$ 312 was affected most heavily. Rangaswami (1960a) reported the occurrence of disease in some parts of Madras on the sugarcane varieties Co 449, Co 527 and Fiji B. Thereafter, red stripe have been reported from several states on many varieties in India such as in Maharashtra on Co 419 (Bhide et al., 1956; Albuquerque and Arakeri, 1956; Summanwar and Bhide, 1962), in Punjab on Co 312, (McRae and Desai, 1933; Padwick, 1940; Chona, 1956; Chona and Rao, 1963) in Uttar Pradesh on Co 443, Co 453, Co 527, Co 617, Co 991, Co 1007, Co 1081, Co 1111, Co
1148, Co 1158, Co 1223, Bo 10, Bo 17, and CoS 510 (Rana and Shukla, 1968) and in Bihar on Co 419, Bo 10 and Bo 17. Recently, a high incidence of Red stripe phase was observed in the promising clones at Shakarganj Sugar Research Institute (SSRI), Jhang Pakistan (Hussnain et al., 2011). They reported that, out of 27 variety tested, 16 were found resistant, four moderately resistant, five moderately susceptible and two susceptible. There were no highly susceptible clones. Iqbal and his co-workers (1995) reported that the performance of sugarcane clones by artificial inoculations with the red stripe pathogen varies from natural infection under field condition. Grillo and Azevido (1939) observed that the disease symptoms developed only when inoculation were done at relative humidity higher than 85 per cent. In Rio de Janerio, Grillo (1938) concluded that Top rot is a characteristic symptoms under very humid condition and may cause appreciable injury. Chaudhary et al., (1999) reported up to 38 per cent and 40 per cent reduction in cane yield and recoverable sugar respectively by Top rot. They further observed that the disease incidence was higher in the month of June and July when temperature and humidity were high. Ahmad et al., (1993) reported that red stripe caused a significant reduction in cane weight by 11.71 and 38.11 per cent at the leaf stripe and top rot phase respectively. He further reported that sucrose content of the juice was adversely affected ranging from a sugar loss of 16.13 to 48.39 per cent. In Rio de Janerio and Grillo (1938) reported the greatest loss from the toprot phase, where field losses up to 15 per cent or more have been reported (Egan and Hughes 1958, Martin and Wismer 1961, Vesminsh et al., 1978). Based on the survey in the major sugarcane growing districts in Punjab (India) Kumar et al., (2014) reported maximum prevalence of top rot disease (56.0\% and 54.3\%) in Amritsar district on variety $\mathrm{CoJ} 85$ in 2011 and 2012. The further 
concluded an early variety CoJ 85 more susceptible to the top rot disease.

\section{Taxonomic position}

The taxonomic position of the pathogen of Red stripe (Top rot) has been a lot of controversy among the researchers. The bacterial nature of the disease was established by Lee and Jennings in 1924. The bacterium which causes red stripe was first classified as Phtomonasrubrilineans by (Lee et al., 1925) and then was renamed as Pseudomonas rubrilineans by Stapp (1928) and Bacterium rubrilineans by Elliot (1930). Following the establishment of Xanthomonas, Starr and Burkholder (1942) transferred the red stripe organism to this genus and the taxon accordingly became $X$. rubrilineans. They however, noted that as far as lipolytic activity is concerned the organism does not agree with typical Xanthomonas. Werham (1948) also included it in doubtful species of Xanthomonas. Inspite of such doubts in the $7^{\text {th }}$ edition of Bergey's Manual (Breed et al., 1957) the pathogen was listed as species of Xanthomonas. Martin and Wismer (1961) also followed Bergey's disposition of this organism. They summarized information on this disease as it occurs on sugarcane. This includes history, geographical distribution symptomatology, morphological characters, biochemical and physiological characters of the pathogen, alternate host, transmission and control. Cotterll-Dormer (1932) noted that the thermal death point of the red stripe pathogen is about $51^{0} \mathrm{C}$. Hayward (1962) after a detailed study concluded that it is erroneous to include red stripe organism under Xanthomonas. He stated that the valid name of this is Pseudomonas rubrilineans (Lee et al., 1925) Stapp. Subsequently, Dye (1963) supported Hayward's conclusion and Bradbury (1967) adopted the Pseudomonas rubrilineans. Summanwar and Bhide (1962) noted that the pathogen is indistinguishable from Xanthomonas rubrilineans in most of the morphological cultural and physiological characters but differed in not being capable of infecting maize. Chona and Rao (1963) isolated both Xanthomonas rubrilineans and Pseudomonas rubrilineans from diseased plant of variety Co-312. According to them the later appeared to be more virulent than the former. Dange and Payak (1972) reported that the red stripe disease in sugarcane and stripe disease in maize were caused by the same pathogen and that the earlier reports from India (Desai, 1933; Albuquerque and Arakeri, 1956; Bhideet al., 1956; Rangaswami 1960 a and b; Summanwar and Bhide, 1962; Chona, 1958; Chona and Rao, 1963 and Ullasa et al., 1967) of Xanthomonas rubrilineans on both sugarcane and maize are probably erroneous. Vesminsh et al., (1975) from Cuba reported that the disease is caused by a number of bacteria viz., Pseudomonas floridana, Xanthomonas rubrilineans, Pseudomonas taxon, Bacillus sacchari and Phytomonasholoi (Pseudomonas syringae). Dange and Payak (1973) reported that the red stripe pathogen should be classified under the genus Pseudomonas. Esquivel (1975) recorded red stripe disease due to Xanthomonas rubrilineans in Panama. Hughes (1978) has reported that the red stripe disease is caused by Pseudomonas rubrilineans (Lee et al., 1925) Stapp. Rangaswami (1960a, 1960b) identified the pathogen as Xanthomonas rubrilineans (Lee et al., 1925) Starr and Burkholder. In Bergey's Manual (1957), 149 species of Pseudomonas have been listed. A detailed review of Pseudomonas has been published by De Ley (1964). The genus includes saprophytes, plant animal and human pathogens. It encompasses heterotrophic, gram negative, asporogenous, fluorescent and non-fluorescent rod like bacteria with a tuft of polar flagella and forms not too sensitive to Erythromycin Chloramphenicol etc. It has often been confused in the past with 
Xanthomonas. Chona and Rao (1963) reported that Pseudomonas rubrilineans produced green fluorescent pigment, although they have not specified the medium in which fluorescence was observed. Sands et al., (1970) studied plant pathogenic Pseudomonas including three strains of Ps. rubrilineans $(359,118,920)$ from the National Collection of Plant Pathogenic Bacteria, Harpenden, England and they were classified in nonpigmented, slow growing non-fluorescent group along with strains of Ps. solanacearum(Smith), Ps. setariae (Okabe) Savulescu and Ps. rubrisubalbicans (Christopher and Edgerton) Hayward. Thus Chona and Rao (1963) are the only authors who have found fluorescence in Ps. rubrilineans but since the isolates have not been studied by others therefore the report thus remain unconfirmed. Hussnain et al., (2011) on the basis of morphological appearance and biochemical characterizations identified the bacteria as Acidovorax avenae subsp. avenae. They reported the bacteria as gram negative, citrate utilization positive, oxidase negative, catalase positive and urease negative. Ramundo and Calaflin (1990) reported that the strains of Pseudomanas avenae (Manns) and Pseudomanas rubrilineans (Lee et al.,). Stapp (1928) observed a minor difference between the physiological and biochemical characteristics but no differences were reported in pathogenicity, host range, cellular protein profiles, direct fluorescent straining and dotimmumo binding assays of the two pathogen strains but were distinctly different from other non-florescent pseudomonads. They further proposed that the two strains be regarded as a single species, retaining the name Pseudomanas avenae. Shivaji et al., (1989) first identified Pseudomonas fluorescens, Pseudomonas putida and Pseudomonas syringae from continental Antarctica based on their morphology, biochemical and physiological characteristics and mole present
$\mathrm{G}+\mathrm{C}$ of their DNA. Cottrell-Dormer (1932) showed that top rot and red stripe were manifestation of the same disease and were caused by the same organism (Pseudomonas rubrilineans). Orian (1956) reported a disease with symptoms similar to those of red stripe (Pseudomonas rubrilineans) on Mauritius in 1954 on Barbados varieties B3337 and B37161. Patro et al., (2006) reported that the pathogen associated with the top rot phase of sugarcane red stripe disease in India as Acinetobacter baumannii.

\section{Host Range}

This pathogen has wide host range. Apart from sugarcane (Saccharum officinarum L.) it is known to attack Sweet corn [Zea mays var. saccharats (Sturtev.) Barley], field corn [Zea mays var. identitata (Sturtev.) Barley], Johnson grass [Sorghum halepense (L.) Pers.], brown corn [Sorghum vulgare var. technicum (Koren) Jav.], Sudan grass (Sorghum sudanense (Piper) Stapf.), Tambuki grass [Sorghum verticilliflorum (Steud) Stapf.], Sorghum plumosum Beauve., Sorghum plumosum Pers. (var. Impphee and Sacchaline) (Lee et al., 1925). CotterllDormer (1932) and Orian (1956) reported that the red stripe pathogen also exists on Paspalumnutans Lam. and P. paniculatum L. in Mauritius. In India, Ps. rubrilineans has been found to infect Zea mays, sorghum vulgare, Pennisetum typhoideum, Panicum antidotale, Brachiaria mutica and Hordeum vulgare (Rangaswami, 1960b; Summanwar and Bhide, 1962; Ullasa et al., 1967). Dange and payak (1972) reported Paspalum nutans, Paspalum paniculatum, Pennisetum purpureum, Setaria verticillata and sorghum halepense also to be the host of Pseudomonas rubrilineans.Hu et al., (1997) investigated the relative virulence of strain of Acidovorax avenae to their hosts and reported that the strains of Acidovorax avenae subsp. avenae were more virulent to sweet corn than maize 
and sugarcane, but less virulent or avirulent to oat. He also reported that the passage of weakly virulent strains of subsp. avenae through sweet corn did not affect strain virulence. He further reported that the Acidovorax avenae subsp. cattleyae did not caused symptoms in Cattleyae sp. and the strains of Acidovorax avenaes subsp. citrulli were more virulent to cucumber than to melon. They were more virulent in the young tissues of their respective hosts (sweet corn and cucumber) at $27-30^{\circ} \mathrm{C}$, with expression at higher temperatures being limited by the thermal tolerance of the plants. He further developed a general equation relating symptom expression to inoculum concentration where simple linear equation related the logarithm of lesion number to the logarithm of inoculum concentration. He concluded that the intercept values in the equation for each strain can be considered to be an expression of the heterogeneity of pathogenicity of inoculums, whereas the gradient gave an expression of the relative virulence of infective cells. Xie et al., (2011) reported Acidovorax avenae subsp. avenae formerly Pseudomonas avenae as a phytobacterium which causes several plant diseases with economic significance including rice, corn, oats, sugarcane, millet, and foxtail. He further reported that the draft genome sequence of strain RS-1, which was isolated from rice shoots in rice causing bacterial stripe of rice field in China.

\section{Perpetuation and survival of the pathogen}

Barnum (1925) reported that pathogen of sugarcane survived for 37 days in unsterilized soil and 41 days insterilized soil. Lee (1925) observed that out of 1000 setts taken from diseased plants, only one transmitted the disease. Thus it does not cause a true vascular disease and therefore is rarely carried through setts. The organism is found more in the parenchyma and sheath cells than in the phloem and xylem. Transmission of the disease by using infected knives in the preparation of the seed either failed to occur or occurred in only a very small percentage of cases. Rangaswami and Thirunavukarasu (1964) reported that Xanthomonas (Pseudomonas) rubrilineansfrom sugarcane survived 84-112 days in sterile soil and 3-63 days in unsterilized soil as suspension. Longevity was shorter when these species were added with their respective host tissues.

\section{Environmental factors in relation to disease development}

The pathogen is spread by wind and rain in warm humid weather. Bell (1942) reported that because of the failure of the usual monsoon late summer rains, red stripe $(X$. rubrilineans) and top rot were not at all prevalent but the dry spring of 1941 included some stem rot in over mature canes, in a field at Maringa where patches of severe top rot were present. Heavy dressing of filter press mud was made on these places, with the result that top rot gradually declined. Lee et al., (1925) stated that the red stripe of sugarcane is a wet weather disease. In an epidemiological study, carried out by Yonzone et al., (2014) reported that the maximum lesion length of $32.28 \mathrm{~cm}$ on CoJ 85 and $27.72 \mathrm{~cm}$ on $\mathrm{CoJ} 88$ was found 32 days after inoculation. They further reported the incubation period of 7 days and 9 days on development of disease symptom and ooze formation when inoculated with four isolates RS-2, RS-3, RS-6 and RS-8 on variety CoJ 85.

\section{Sensitivity of the pathogen to antibiotics}

Pseudomonas has been found less sensitive to Erythromycin, Erythrocinelactobinate and Chloramphennicol. Dange and Payak (1974) found that Pseudomonas rubrilineans is quite sensitive to Terramcin as well as 
Streptocucline. However Hussnain et al., (2011) reported that the bacterium Acidovorax avenae subsp. avenae showed best results with Ampicillin and Vancomycin at 75 and $25 \mu \mathrm{g} / \mathrm{ml}$, respectively when compared with other saprophytic bacteria. Thind et al., (1984) reported that Streptocycline alone and its combinations with Glycerine or Copper sulphate proved more effective for controlling leaf stripe of maize than Agrimycine-100, Potassium permanganate and Blitox-50. Patro et al., (2006) reported that causal organism of red stripe was highly resistant to Ampicillin, but was susceptible to the rest of the antibiotics tested (i.e., Streptomycin, Kanamycin and Rifampicin).

It may be concluded from the foregoing discussion that the Red stripe/Top rot disease once considered as the minor disease is gaining its importance in many recommended varieties as well as in areas with changing climatic conditions. Therefore a proper adaptation measures, as well as development of resistant cultivar for proper management of this disease should be adopted so that the economy of farmers remains unaffected.

\section{References}

Agnihotri, V.P. 1990. Diseases of Sugarcane and Sugarbeet, Oxford and IBH Publ Co New Delhi pp 264-71.

Ahmed, M., Malik, K.B and Tiwana, H.A. 1993. Top rot a bacterial disease of sugarcane in Pakistan. Paper presented on $4^{\text {th }}$ National Conference of Plant Scientists. Feb. 16-18, Faisalabad, Pakistan.

Albuquerque, M.J and Arakeri, H.R. 1956. Sugarcane red stripe disease on Co-419 Indian Sugar, 6: 323-24.

Anonymous, 2015. Department of Agriculture, Government of Punjab. http://agripb.gov.in/home.php?page=su gar.
Barnum, C.C. 1925. The activities of the red stripe organism in the soil Red stripe Disease Studies Expt St H S P A Path Dept., pp. 49-64.

Bell, A.F. 1933. Thirty third Ann. Rept of Division of Plant Pathology Queensland Bureau of Sugar Expt St., pp. 54-61.

Bhide, V.P., Hedge, R.K., Desai, M.K. 1956. Bacterial red stripe disease of sugarcane caused by Xanthomonas rubrilineans in Bombay State. Current Science, 25:30.

Bolle, P.C. 1929. The red stripe disease Arch Suikerind Nederl- Indie, Dee 1 iii. Xxxvii, pp. 1147-1218.

Bradbury, J.F. 1967. Pseudomanas rubrilineans C. M. I. Description of pathogenic fungi and bacteria. Set 13, No. 127.

Breed, R.S., Murray, E.G.D and Smith, N.R. 1957. Bergey's Manual of Determinative Bacteriology pp. 1094. Williams and Wilkins Co., Baltimore.

Chaudhary, M.A., Ilyas, M.B and Khan, M.A. 1999. Effect of top rot of sugarcane on yield quality, relationship of temperature and humidity with disease development and screening for varietal resistance Pakistan Journal of Phytopathology. 11: 126-129.

Chona, B.L and Rao, Y.P. 1963. Association of Psedomonas rubrilineans (Lee et al.,) Stapp. With the red stripe disease of sugarcane in India. Indian Phytopathology16:392-93.

Chona, B.L. 1956. Presidential address for the pathology section Proc ISSCT9: 975-80.

Chona, B.L. 1958. Some diseases of sugarcane reported from India in recent years Indian Phytopathology11: 1-9

Christopher, W.N and Edgerson, C.W. 1930. Bacterial stripe diseases of sugarcane in Louisiana Jour Agricultural Research41:259-67.

Cook, M.T. 1929. Tresenfermedades de la Cana de Azucarencontrades recientemente en Puerto Rico Rev 
Agrilcultural Puerti Rico, 22:15-16.

Cottrell-Dormer, W. 1932. Red-Stripe disease of sugarcane in Queensland. Bull. Bur. Sugar Exp. Stn Div. Pathology. 3: 2559.

Dange, S.R.S and Payak, M.M. 1972. Additional hosts for red stripe disease of sugarcane Sugarcane Pathology News Lett., 9: 8.

Dange, S.R.S and Payak, M.M. 1973. The taxonomic position of the pathogen of red stripe of sugarcane. Sugarcane PatholNewsletter.10:25-28.

De Ley, J. 1964. Pseudomonas and related genera Annual Review of Microbiology, 18: $17-46$.

Desai, S.V. 1933. Occurrence of the red stripe disease of sugarcane in India Proc $20^{\text {th }}$ Indian Science Congress (Patna), pp 6162 (abstr.)

Dye, D.W. 1963.Comparative study of the biochemical reactions of additional Xanthomonas spp. New Zealand Journal of Science 6:483-486.

Edgerton, C.W. 1959. Sugarcane and its diseases, $2^{\text {nd }}$ ed., Louisiana State Univ. Press, Baton Rouge, p. 301.

Egan, B.T and Hughes, C.G. 1958. Top rot can cause losses Cane Grow $Q$ Bulletin, 22: $35-36$.

Elliot, C. 1930. Manual of Bacterial Plant Pathogens pp. 349, Baltimore, Trindall and Cox, U. S. A.

Esquivel, E.A. 1975. Two important sugarcane diseases in Panama. Fitopathologia, 10: 117-19.

Faris, J.A. 1927. Report upon a bacterial red stripe disease of sugarcane in Cuba. Unpublished. Dec 8.

Fors, A.L. 1978. Red stripe in Central America Sugarcane Pathology Newsletter, 21: 25-26.

Grillo, H.V.S. 1938. On the red stripe disease in Brazil. Proc $6^{\text {th }}$ Congress International Society of Sugar Cane Technology, 427-30.
Grillo, M.S.G and Azevedo, N. 1939. On the red stripe of sugarcane in Brazil. Pric International Society of Sugar Cane Technology 6: 428-30.

Hayward, A.C. 1962. Studies on Bacterial Pathogens of Sugarcane. II. Differentiation, Taxonomy and Nomenclatural of the bacteria causing red stripe and mottled stripe diseases. Mauritius Sugar Industry Research Institute, 13: 13-27

Hu, F.P., Young, J.M., Triggs, C.M and Wilkie, J.P. 1997. Pathogenic relationships of the subspecies of Acidovorax avenae Australas Plant Pathology 26: 227- 38.

Hughes, C.G. 1978. Diseases of sugarcane- A review PANS 24: 143-59.

Hussnain, S.Z., Haque, M.I., Mughal, S.M., Shah, K.N., Irfan, A., Afghan, S., Shahazad, A., Batool, A., Khanum,P., Hussain, K., Nawaz, K., Hassan, M.N and Hafeez, F.Y. 2011. Isolation and biochemical characterizations of the bacteria (Acidovorax avenae subsp. avenae) associated with red stripe disease of sugarcane African Journal of Biotechnology 10:7191-97.

Iqbal, M., Rahman, S., Talukdar, I., Kabir, A.K.M., Rahman, M.S. 1995. Reaction of some promising clones to red stripe disease. Bangladesh Journal of Sugarcane, 17: 123- 26.

Lee, H.A and Jenning, W.C. 1924. Bacterial red stripe disease of tip canes Exper. Hawaii Sugar Plant Assoc. Exp. Stn, Agricultural Chemestry Circulation 42: 10.

Lee, H.A and Pierce, D.W. 1928. Bacterial red stripe disease of sugarcane in countries of the Pacific. Phytopathology 18:945.

Lee, H.A. 1925. Transmission of red stripe disease by cane cuttings Red stripe Disease Studies Expt St $H \quad S \quad P \quad A$ Pathology Department pp.32-35. 
Lee, H.A., Purdy, H.A., Barnum, C.C and Martin, J.P 1925. A comparison of red stripe disease with bacterial diseases of sugarcane and other grasses. Red Stripe Disease Studies. Experiment Station H S P A Pathology Department pp. 64-74.

Lyon, H.L. 1922. A leaf disease of the Tip cane Proc Hawaiian Sugar Planters Association: 246.

Martin, J.P and Wismer, C.A. 1961. Red stripe In: J.P. Martin, E.V. Abbott and C.G.Hughes (Editors), Sugarcane Diseases of the world Vol. I. Elsevier Publication, CO. Amsterdom.pp.109126.

Martin, J.P. 1938. Sugarcane diseases in Hawaii Advertiser Publication Corporation, Honolulu Hawaii pp.295.

Matsumoto, T. 1952. Monograph of sugarcane diseases in Taiwan. Taipei, Taiwan.

McRae, W and Desai. 1933. New diseases reported during the year 1932 International Bulletin of Plant Protection 7: 79-80.

Okabe, N. 1933. Bacterial diseases of plants occurring in Formosa II Journal Society of Tropical Agriculture 5: 26-36.

Orian, G. 1956. Occurrence of disease similar to red stripe of sugarcane in Mauritius Proccedings ISSCT9: 1042-48.

Padwick, G.W. 1940. Science Report of Agricultural Research Institute New Delhi 105 Pp.

Patro, T., Rao, V.N., and Gopalakrishnan, J. 2006. Association of Acinetobacter baumannii with a top rot phase of sugarcane red stripe disease in India Indian Phytopathology 59: 501-02.

Ramundo, B.A and Claflin, L.E. 1990. Demonstration of synonymy between the plant pathogen Pseudomonas avenae and Pseudomnas rubrilineans Journal of General Microbiology 136. 2029-33.

Rana, O.S. and Shukla, R. 1968. Ratoon stunting disease of sugarcane and its control in Uttar Pradesh. Indian Sugar 18: 541-45.

Rands, R.D and Dopp, E.J. 1932. An epidemic outbreak of red stripe disease of sugarcane and the reaction of some seedling progenies. Proc $4^{\text {th }}$ Congress International Society of Sugar Tech Bulletin, Pp. 46.

Rangaswami, G and Rajagopalan, S. 1973. Bacterial Plant Pathology, Tamil Nadu Agriculture University, Coimbatore.

Rangaswami, G. 1960a. Studies on two bacterial diseases of sugarcane. Current Science 29: 318-19

Rangaswami, G. 1960b. Further studies on bacterial gummosis and red stripe disease of sugarcane Journal of Annamalai University 22:135-50.

Rangaswami, G. 1975. Present suatus of bacterial diseases of crop plants and their control Pesticides 9: 8-13.

Rangaswami, G. and Thirunavukarasu, V. 1964. Studies on survival of plant pathogens added to the soil Indian Phytopathology 17: 202-07.

Ricaud, C., Egan, B.T, Gullaspie, Jr. A.G., and Hughes, C.G. 1989. Diseases of Sugarcane-Major diseases. Elsevier, New York pp. 399.

Sands, D.C., Schroth, M.N and Hildebrand, D.C. 1970. Taxonomy of Phytopathogenic Pseudomonas Journal of Bacteriology, 101: 9-13.

Shivaji, S., Rao, N.S., Saisree, L., Sheth, V., Reddy, G.S and Bhargava, P.M. 1989. Isolation and identification of Pseudomonas spp. from Schirmacher Oasis, Antarctica Applied Environmental Microbiology 55: 767.

Stapp, C. 1928. In Sorauer's Handb. Pflanzenkr 2:35, Berlin.

Starr, M.P and Burkholder, W.P. 1942. Lipolytic activity of phytopathogenic bacteria determined by means of sprite blue agar and its taxonomic 
significance. Phytopathology32: 598604.

Subramaniam, L.S. 1936. Diseases of sugarcane and methods for their control. The Imperial Council of Agricultural Research, (Delhi) India, Misc Bulletin 10.

Summanwar, A.S. and Bhide, V.P. 1962. Bacterial red stripe disease of sugarcane - Saccharum officinarum caused by Xanthomonas rubrilineans var indicus in Maharashtra Indian Journal of Sugarcane Research Development, 6: 65-68.

Thind, B.S, Randhawa, P.S and Soni, P.S. 1984. Chemical control of bacterial stalk rot (Erwinia chrysanthemi pv. zea) and leaf stripe (Pseudomonas rubrilineans) of maize Zeitschriftfuer Pflanzenkrankheiten und Pflanzenschutz (Z. Pflanzenkr. Pflanzenschutz.) 91: 424-30.

Tryon, H. 1923. Top rot of sugarcane Bulletin Bur Sugar Experiment Station Division of Pathology. I.

Ullasa, B.A., Mehta, Y.R., Payak, M.M and
Renfro, B.L. 1967. Xanthomonas rubrilineans on Zea mays in India Indian Phytopathology20: 77-78.

Vesminsh, G.E., Chinea, A and Canada, A. 1978. Causes de la propagacion y desarrollo en Cuba de la enfermedadnayarojabacteriana de la cana de azucar. Cienc Agriculture 2: 5364.

Wernham, C.C. 1948. The species value of pathogenicity in the genus Xanthomonas. Phytopathology 38: 28391.

Xie, G.L., Zhang, G.Q., Liu, H., Lou, M.M., Tain, W.X., Li, B., Zhou, X.P., Zhu, B and Jin, B.Z. 2011. Genome Sequence of the Rice-Pathogenic Bacterium Acidovorax avenae subs pavenae RS-1 Journal of bacteriology 18: 5013.

Yonzone. R., Kumar, B and Devi, M.S. 2014. Pathogenic Variability among Different Isolates of the Red Stripe / Top Rot Causing Pathogen in Punjab State. Environment \& Ecology 32(3): 873877.

\section{How to cite this article:}

Rakesh Yonzone and Maimom Soniya Devi. 2018. Red Stripe/ Top Rot Disease of Sugarcane: A Review. Int.J.Curr.Microbiol.App.Sci. 7(01): 1469-1478. doi: https://doi.org/10.20546/ijcmas.2018.701.179 